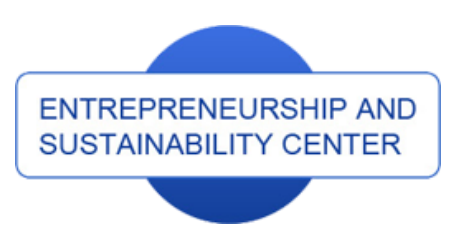

Publisher

http://jssidoi.org/esc/home

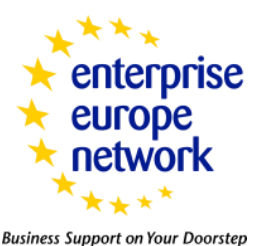

Business Support on Your Doorstep

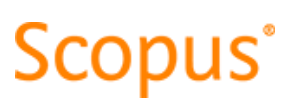

1) Clarivate

Analytics

\title{
SUSTAINABLE ECONOMIC DEVELOPMENT AND POST-ECONOMY OF ARTIFICIAL INTELLIGENCE
}

\author{
Oktay Mamedov', Yuri Tumanyan², Oksana Ishchenko-Padukova ${ }^{3}$, Irina Movchan \\ 1,2,3,4 Southern Federal University, Bolshaya Sadovaya str. 105/42, 344006 Rostov-on-Don, \\ Russian Federation
}

E-mails:1oktaj-mamedov@yandex.ru ; ${ }^{2}$ yrtumanyan@sfedu.ru ; ${ }^{3}$ oaishenko-padukova@sfedu.ru ; ${ }^{4}$ ivmovchan@sfedu.ru

Received 15 September 2018; accepted 13 December 2018; published 30 December 2018

\begin{abstract}
The world economy is currently becoming involved into a most dangerous crisis of systemic nature: into the transition from postindustrial type economy to post-economy of artificial intelligence (AI). The portent to such a "transition crisis" manifests itself in the fact that the wage level has become stable in all industrially developed countries, however, the center of revolutionary qualitative change has by now shifted to a change of the employment structure - the proportion of less qualified workers group keeps decreasing, what is more, exponentially. Meanwhile, bearing in mind that live labor is the major source of increment of national wealth in sustainable postindustrial economy, it can be stated that it has reached the limit of its constructive capacities and urgently demands bringing the "personal factor" of production beyond boundaries of the latter. It is "post-economy of artificial intelligence" that is up to this imperative. It is characterized by the priority of the new source of energy and social communicating technology, it forms a brand-new economic basis which exceeds the potential of postindustrial production. What actually happens is the transition from the "economy of scarcity" to the "economy of abundance". This entails new architectonics of a social order. In post-economy of artificial intelligence, software-controlled production, service and transaction structures gain the global nature initially. As a result, "artificial intelligence" appears to be the creative software. In the new situation, the emergence of more complicated forms of economy is inevitable. Market institutions - competition, innovation, marketability - will be put to comprehensive tests too. A bunch of theoretical questions arise that can be answered by the economic science. It is searching for answers to the set questions that is in the focus of attention of this paper.
\end{abstract}

Keywords: artificial intelligence; post-economy; sustainability; transformational change; fundamental properties; scientific progress

Reference to this paper should be made as follows: Mamedov, O.; Tumanyan, Y.; Ishchenko-Padukova, O.; Movchan, I. 2018. Sustainable economic development and post-economy of artificial intelligence, Entrepreneurship and Sustainability Issues 6(2): 1028-1040. http://doi.org/10.9770/jesi.2018.6.2(37)

JEL Classifications: E19, P10, P48 


\section{Introduction}

Potential economic preferences formed by using artificial intelligence (AI) technologies in traditional and creative sectors of the national economy imply the wide-ranging use of artificial intelligence technologies on the basis of working out the national development strategies that help increase the economic growth rates, labor and capital productivity, diversification of sectoral makeup of production, and improvement of investment climate, because the productivity of artificial intelligence exceeds all existing processes of automation and mechanization. Hence the main task is both to create artificial intelligence technologies and to ensure access to them for as many as possible strategically important economic subjects. The paper discusses priority post-economic, meta-economic and institutional barriers hindering the implementation of artificial intelligence technologies. It provides grounds for particularities of the process of investing into artificial intelligence technologies and estimates the influence of artificial intelligence on the spheres of production and consumption.

In the contemporary conditions, the extent of application of artificial intelligence technologies is expanding, and no sector can avoid their effect. Meanwhile, the influence of artificial intelligence on various spheres of the national economy has a transformational nature and one enhancing the competitiveness. Not only do technologies of artificial intelligence alter the technical basis of production, but they also transform the configuration of social and economic relations being formed in it as well as the mechanisms of developing and fulfilling the optimum economic solutions.

\section{Post-economy as an object of social analysis}

Social science broadly uses the definition "post-" (post-capitalism, post-industrialism, or post-modernism) which is intended to characterize new social forms emerging as a denial of the already existing ones. It is in this meaning that the category "post-economy" is employed owing to which "the entire history of economic management of the human society can be represented as a chain of transitions from non-market economy to market one, and then, if the ideas of Hegelian dialectic are to be adhered to, from market economy back to post-market or post-economic society" (Ushankov, 2014). Certainly, this is a simplified interpretation of Hegelian dialectic because throughout the economic progress of the humanity the economic achievements never get denied but are preserved and fulfilled in a modified way.

According to the main premise of the scientific theory of public production, it is the difference in the way how its personal and material factors are connected that acts as the difference between stages of economic development. At the early stages of the rise of public production, direct, immediate connection was objectively due to limited social parameters of the emerging economy (Steensma and Lyles, 2000; Cábelková and Strielkowski, 2013; Ćábelkova et al., 2015). Back then, its boundaries were specified by the limits of efficiency of the primitive production and consumption commune. As for the genuine economy, it is formed beyond the production and consumption commune, and the humanity will never return to it - losing (with such a return) all its social and technical gains (Abrhám et al., 2015). Conversely, the entire public production practice discovers it develops by no means for confirming the correctness of Hegelian dialectic but obeying the laws of achieving social efficiency. The authors of this paper are united by the methodology adopted by them for analyzing the social essence of posteconomic stage of public production. According to the methodology, the said stage differs from all the previous ones by the fact that within it the economic problems are resolved by scientific and technical revolution, the systemic breakthrough of which takes the shape of "artificial intelligence". Some sketchy success in this direction can already be seen today: communicative technologies that have overcome the monopoly of the state services (mail, telegraph, telephone), service centers that have made independent orders (of tourist trips, transport tickets, state services) possible, and the time wasted for shopping has been replaced with an opportunity of viewing the 
offers remotely (in the Internet-based shops). Accretion of technical and social advance - this is the essence of the post-economic development stage of public production.

\section{Artificial intelligence within the coordinates of economic theory}

Being the newest form of systemic automation of macroeconomics, artificial intelligence is of interest for both the society and the economists first and foremost as a unique factor of economic growth. Artificial intelligence gains especial economic significance in the status of a self-learning device which can automate processes that for many decades have been believed to be non-automated. No less attention of the economists is drawn by the main consequence of economic growth as a result of fulfilling the production potential of artificial intelligence optimization of income distribution between labor and capital (see e.g. Nilsson, 1984; Kalyugina et al. 2015; Ehrenberger et al. 2015; Dirican, 2015; Koudelková et al. 2015; Strielkowski and Č́ábelková, 2015; Chen et al., 2016).

This means that artificial intelligence itself, with its technological, cybernetic, informational and other features, is not and cannot be an object of attention of both the economic science and the economists. Meanwhile, forecasting the influence of creation of artificial intelligence on those essential properties of post-economy the total of which makes up its inherent object uniqueness is quite a different story.

So what fundamental properties of post-economy - as a result of fulfillment of the public production potential of artificial intelligence - are the case?

Numerous special studies have allowed building the most general, abstract, logical model of the efficient economy the integral elements of which are the private property and entrepreneurship emerging on the basis of the latter; the state property serving the interests of the society; the state and private partnership; fair competition of all forms and kinds of property; countering the monopoly abuse, marketability, market principle, innovation, and creativity (Lisin et al., 2015; Lisin et al., 2016; Strelkowski et al., 2016b or Štreimikiené et al. 2016; Zemlickiene et al., 2017; Tvaronavičienè 2018; Tvaronavičienė et al. 2018). These are the "bricks" of which the present-day building of the economy is constructed. With numerous systemic concepts in economics, the quantity and composition of the listed attributes may vary considerably. Anyway, each of the above "brick" will inevitably experience the transformational action of the production and technical potential of artificial intelligence as that is fulfilled.

Pointing out the transformational nature of action of artificial intelligence on fundamental elements of the economy means that the essential properties of the elements will remain the same but the forms they are fulfilled and expressed in will experience important change. With this approach, the task of economic science is to perform preventive forecasting of the expected transformational change in order to introduce the relevant alterations into the mechanisms of functioning of "post-economy of artificial intelligence" and to develop the long-term macroeconomic policy.

\section{On methodology of exploring post-economy}

With the economic science being made up of generalization of their results, actually, theoretical studies impose special requirements for the nature of reasoning and logic of presentation of the results of the analysis conducted. The principal problem of theoretical research consists in its deductive nature. Moreover, such a deductive nature of theoretical research is the only possible form of conducting it. It goes without saying that situations are quite possible when the final theoretical provisions of a completed study can be backed up by certain economic statistical material. Yet the cases of such a "synthesis" of the essence and the phenomenon are extremely rare, 
which is explained by their failing to coincide within the objective reality fragment under study. Meanwhile, it is exactly such incongruity that keeps generating the ordeals of scientific cognition: had the essence and the phenomenon coincided, there would have been no need of science. For the sphere of economy, economic processes being split into the essence and the phenomenon (and opposition thereof) has turned into the condition of being of all economic forms, institutions and instruments. However, the very division emerges in fact only since the point of production growing on into the commodity production (first - simple one, and then - into capitalist one).

Will the "artificial intelligence" work its way through this division and opposition? It is very doubtful because for these economic foundations of the market production form have to wither away - public division of labor and private property for the results thereof. Meanwhile, for such withering away, tectonic change is necessary in the proportion of production (productive forces) and economy (public production forms) (Čajka et al., 2014; Strielkowski and Weyskrabova, 2014; or Strielkowski et al., 2016a).

Therefore, what transformational change in the economy can be forecast with the advent of the "artificial intelligence" phenomenon as that of self-learning programmed devices ensuring the maximum efficiency of production and technological systems?

The authors forecast three essential alterations in the market organization of public production: 1) revival of the "known market" institution; 2) reduction of the sphere and volume of transaction costs; 3) increase of the extent of institutional regulation of the economy. Now the mentioned changes are going to be discussed in the sequence.

1. Saying goodbye to the medieval times proved to be saying goodbye to a special type of market too - one that remained in the economic history as the "direct order market". In those distant centuries, such an institution (a stage necessarily preceding the rise of the full-fledged commodity production) emerged due to the medieval sphere of creation being crammed into the boundaries of the fortress walls of the medieval cities (back then, with subsistence economy being still widespread in agrarian settlements, handicraft industry could only exist in cities). The medieval handicraft market itself was in fact a kind of subsistence production and consumption commune, too. As for nowadays, the revival of market as a "direct order institution" takes place on the contemporary technical substrate which enables each potential buyer (customer) to independently determine the buying method technology - either via a dealer (specialized sales point), or by means of a direct order with the immediate manufacturer. With regard to this, the practice of "mixed buying" can be stated for the present time that is transitional in nature and will be terminated as soon as one of the two forms of buying proves its inaccessible efficiency as compared to the other one. The transition from the "known" market that had prevailed for several centuries to an "unknown" market meant a revolution in organizing the production. In fact, this transition blessed the mastery of commodity forms with non-commodity public production which was then in progress. As soon as production governed by "artificial intelligence" becomes firmly established, the reverse movement will be seen, this time one from the "unknown" market prevailing at present (i.e. from a known manufacturer working for an unknown customer) to the "known" market (i.e. from a known manufacturer working at the order of a known customer). This is also a revolution in economy, and it will have some major consequences.

2. A known market differs from an unknown one by its objectively reducing the quantity of intermediary links. This renders the economy cheaper owing to withdrawal of intermediary economic subjects, which means curbing down the ever-swelling transaction costs. The nearest consequence of decreasing the transaction costs volume is to be the distinct cutback of employment in the intermediary sphere. As a result, tax revenues of the society will go down while the budget spending on supporting the new group of the unemployed will grow. However, the most important consequence will be the spheres of production and consumption drawing closer to each other, i.e. a kind 
of revival of the production and consumption integrity, which changes essentially the structure and mechanisms of functioning of the entire economic system.

3. One more consequence of the fundamental kind is the new way of behavior of the economy. For all centuries, the humankind has been trying to unthread the mystery of the intricate nature of economic development. It has succeeded in it - the cyclical nature of economic dynamics has been revealed, as well as the role of investments, leadership of entrepreneurship, the necessity of macroeconomic state regulation, and the monetary and fiscal instruments of this regulation. Nevertheless, all the above have been concealing the main factor of viability of the economic sphere - the unpredictability of its behavior, the very unpredictability the elimination of which would at the same time mean the end of self-propulsion of the economy. Public regulation of public production has its reasonable scope and, therefore, reasonable limitations. Exactly where the category of "unpredictability" emerges hiding the category of "randomness" behind it, there the scientific treatment of "unpredictability" generated by "randomness" has to be turned to. Specialists studying the importance of unpredictability (randomness) in economic development professionally come to a conclusion which in facts "rehabilitates" the unpredictability. They state that "it is extremely difficult to forecast anything in the economy at present: any unpredictable fact (which could be foreseen in principle too) can radically change the direction of its movement". A conclusion of the Oxford team of physicists and mathematicians saying that "extreme price movements in financial markets happen far more often than would be expected by chance" (The Economist, 2001) is also in line with the thesis.

Unpredictability, randomness, uncertainty, or stochasticity - this integral fundamental property of the economy has for a long time been the subject of special exploration in the modern economic studies enabling the scientists to make some important theoretical conclusions (see e.g. Assessment methods for efficiency indicator, 2013; Malakhov and Pilnik, 2013; Vorontsovskiy and Viyunenko, 2016; Jensen and Palokangas, 2007; Balitskiy et al. 2014). In particular, a group of economists suggested that multiplicativity is inherent in uncertainty too: the higher its extent is, the higher the average rate of "preventive saving" is. Due to this motive, in the uncertain economic conditions, consumers save much more than the usual norms of savings - in order to secure themselves from negative surprises. As a result, higher savings lead to reduced consumption volumes - and entail the bunch of crisis consequences (Fleming, Pang, 2004; Kendrick, 2005).

\section{Strategic consequences of post-economy of artificial intelligence}

The current development trends of the global world processes bring about the necessity of creating a new national strategy of working out and implementing artificial intelligence. Many countries spend enormous financial funds for supporting research in this area and encourage various innovation and creative projects. On the one hand, artificial intelligence is a global innovation constituent of societal development, and on the other hand - it is a result of human activity. Creation of artificial intelligence is contributed to by players who have vast advantages in the open innovation model - large private business and the state. The range of advance of artificial intelligence will determine its social and economic consequences in the future.

As practice shows, approximately every quarter of a century, there is a revolution of intellectual and digital world that leads to change in the economy. In the last third of the $20^{\text {th }}$ century, transformation has given the humanity the integrated circuits - processors and microchip memory which accelerated the computation immensely. At the end of the last century and the early $21^{\text {st }}$ century, the opportunity of connecting digital processors to each other has been found. Computers united in local and global networks by means of telephone and satellite data transfer. The Internet has become commercialized. It is here that the virtual economy is born, and production processes and other physical actions come to be performed in online systems. So regional character and geographical location lose their relevance. 
The International Journal

ENTREPRENEURSHIP AND SUSTAINABILITY ISSUES

ISSN 2345-0282 (online) http://jssidoi.org/jesi/

2018 Volume 6 Number 2 (December)

http://doi.org/10.9770/jesi.2018.6.2(37)

The contemporary high-tech digital transformation of the economy which accelerated the creation of artificial intelligence took place in the second decade of the $21^{\text {st }}$ century. It promoted the extensive use of artificial intelligence not only in production but also in other spheres - in medicine, education, consumption, service and attendance etc. As a result, methods and algorithms of recognition have been created. The contemporary production and consumption have gained the computer "eyesight". Importantly, new algorithms of artificial intelligence use the data autonomously and form various groups and associations, which used to be within human powers only.

Artificial intelligence is one of the paramount constituents of the fourth industrial revolution which is characterized by the new and newest technologies drawing closer together and complex social and technical systems emerging that permeate each aspect of human life. New technologies and automation are becoming a part of daily life. These achievements in artificial intelligence already have effect on the contemporary economy both in general and in the aspect of personal well-being and financial opportunities of the society.

Technological achievements in the area of artificial intelligence promise to be comprehensive; their consequences can be seen in the area of health care, economy, security and management, as well as in combination with other new and converging technologies that act as a potential for transforming the current society on the basis of improvement of the decision-making process and the quality of life of the people. However, without reasonable assessment of risks and mitigation of their consequences, artificial intelligence may pose a threat for existing vulnerabilities in both economic system and social structures (Markoff, 2015).

First of all, artificial intelligence destroys the traditional business model and occupies its place while already featuring brand new characteristics of production and competition forms. The society gets an impressive boost and incentives appear for mastering the new technologies - and, as always, it is the most efficient subject that wins. This is why one has to become a part of this process in the present-day economy otherwise one can turn into an uncompetitive subject both in production and in the labor market (looking for a job in post-economy of "artificial intelligence"). It is the sphere of education, professional training, scientific research, startups promoting creation of adaptable systems, adaptable financing, and adaptive rules for emergence of new competitive productions and stimulating the existing ones that become the priorities of development of the society.

The authors believe that the economic consequences of artificial intelligence will include both the direct growth of GDP in sectors that develop or manufacture artificial intelligence technology and the indirect growth of GDP at the expense of a higher productivity in the sectors of the economy that use some forms of artificial intelligence. A higher level of artificial intelligence may well yield both higher revenues and employment within the existing production and creation of a totally new economic activity. The productivity of labor in the existing sectors can be enhanced by means of faster and more efficient processes of production and managerial decision-making, as well as by expanding the knowledge and access to information.

The scale of these economic benefits will largely depend on promotion and dissemination of artificial intelligence. If it is an increasingly more critical, more important component of the consumed products, then it will become an inseparable part of life for many people. Another characteristic of this process should be pointed out. The extent of economic effect of artificial intelligence will vary depending on the region and the country, or rather, on the fact whether the artificial intelligence is the prevailing process of economic activity and, therefore, on the primary factor of influence on economic performance in the regional aspect. In fact, given the current progress to accessibility and open source code of development, artificial intelligence has a potential for overcoming the inequality in income and attracting significant benefits both for the developed countries and for the developing ones. For instance, artificial intelligence has a potential for optimizing the production of foods all over the world by means of analyzing the agrarian regions and identifying the conditions for improving the yield of agricultural 
crops. On balance, the broader and the more profound the application of artificial intelligence in a certain region or economic sector is, the higher the expected economic effect is.

While estimating the future economic consequences associated with innovations such as artificial intelligence, it is important to note that it is difficult to predict in advance what exactly applications of artificial intelligence are going to be commercially successful. Moreover, even if success of a commercial project could be determined, it is still quite complicated to assess the extent of relevance of a positive result of artificial intelligence to economic consequences of its use.

Artificial intelligence as a way for transforming the economic reality has quite an effect on economic development, which first and foremost is expressed in reducing the intensity and strain of labor owing to automation of routine and cognitive tasks. Artificial intelligence technologies will influence both the parameters of national economic systems and the configuration of the world market at the expense of changing the industry priorities, alterations in production and consumption, and transforming the financial institutions.

The large-scale implementation of artificial intelligence technologies must contribute to an increase of labor productivity and reduction of technological and production costs, which is bound to lead to a higher efficiency of production. Alongside with that, the opportunities of artificial intelligence technologies will predetermine the change in the sphere of consumption owing to the improvement of quality of consumer goods, their diversification and personalization.

The action of artificial intelligence technologies on two major spheres of public reproduction - production and consumption - will inevitably accelerate the economic growth rates and produce an overall positive influence on the public welfare. However, it is important to bear in mind any negative consequences, too, that may result from massive implementation of artificial intelligence technologies.

\section{The problems of employment in the conditions of post-economy of artificial intelligence}

Another problem is the potential net economic of artificial intelligence and not certain mechanisms leading to economic results, with artificial intelligence being likely to influence both the productivity of labor and employment, and other components of economic growth in many sectors. So early as nowadays, researchers pay close attention to the growth of structural unemployment due to release of low-qualified labor with automation of routine work and machines performing a part of cognitive functions. Currently, it is the technologies of "automated" and "auxiliary" intelligence that prevail which are a way for accelerated performance of routine tasks. Transition to more progressive forms of artificial intelligence - the "extended" one and, subsequently, the "autonomous" intelligence which can make more efficient decisions even without any human efforts needed will lead to freeing up not only low-skilled labor. Meanwhile, there will inevitably appear new jobs and high-tech employment due to the necessity of developing, supporting and operating the artificial intelligence technologies. Such transformation in the labor market will require some relevant measures for regulating the employment and new institutional mechanisms of economic policy. The latter have to be aimed at ensuring an opportunity of learning and further training for workers and at adopting the national doctrines of support for the structural and technological unemployed in sectors which face the greatest scope of implementation of artificial intelligence technologies while having a high percentage of the employed.

Some researchers argue that the growth of high technologies and automation will lead to a marked growth of all kinds of unemployment. With regard to this, they emphasize the increasing "cunning" of artificial intelligence: it can jeopardize both qualified and semi-qualified workers and reduce the size of the middle class (Frey, Osborne, 2017). This is no new reasoning, as the fear of technologies affecting the labor and propelling them into mass 


\section{The International Journal}

ENTREPRENEURSHIP AND SUSTAINABILITY ISSUES

ISSN 2345-0282 (online) http://jssidoi.org/jesi/

2018 Volume 6 Number 2 (December)

http://doi.org/10.9770/jesi.2018.6.2(37)

unemployment was worded by David Ricardo back in the era of industrial revolution - "the substitution of machines for human labour is often very injurious to the class of laborers" (Ricardo, 2003). The economic history of previous "destructive" technologies has shown that employment in certain industries shrunk as a result of technological achievements (matching the net effect of technological advance) but did not lead to its reduction in the long-term cycle. As of today, the labor market is adapted for implementation of new technologies, which manifests itself in new industries being created and, as a consequence, new jobs. This means artificial intelligence ensures a long-term potential of stability for the labor market, even though short-term employment problems are possible.

Another reason of the rapid development of artificial intelligence is the comprehensive automation and cheapening of robotics. For example, within the recent decade, the cost of robots has shrunk by $32 \%$, and for the nearest 10 - 15 years, Bank of America forecasts a further 25\% decrease of the prices (Bank of America; GDP budget-level forecast estimates for 2015-2025). According to experts' forecasts, by 2022, there will have been 3 million jobs more in the world labor market while about 7,1 million jobs will have disappeared, "The Future of Jobs" research published by the World economic forum at the beginning of 2017 records (World Economic Forum, 2017). According to the report by Bank of America, 45\% of production tasks in the USA will have been performed by robots in 10 years, with the current figure being $10 \%$.

Technologies are increasingly being integrated into life of the society, which creates prerequisites for development of artificial intelligence showing objective trends and opportunities for emergence of new artificial intelligence objects. However, it is the human advance too and not only the technical one that has to become the key factor. Hence one of the most important questions of artificial intelligence consists in it having to eliminate the monotonous human activity, thus freeing up the space for creative work. And, naturally, this will pull up quite a lot of other opportunities for people having a low, an average or a high qualification level. Therefore, people will face a dilemma of either changing their sphere of activity or further training in order to be able to interact with the smart machinery.

At present, one of the promising and universal ways out of the crisis economic situation is the "intellectual" scenario - the focus on digital economy and innovations in creation of artificial intelligence. It will be possible to accelerate the process by implementing more advanced methods: e.g. at the expense of reforming the structure of the labor market using various high-tech solutions for automating both intellectual and physical work. Thus, the reduced percentage of employees can be replenished by robotizing the production, including that of non-manual workers: robots begin to replace people in occupations that require interaction with customers.

Most researchers believe jobs implying a high extent of creativity, analytical thinking or interpersonal communication to be the most stable ones (Atkinson, 2013). Implementation and use of artificial intelligence can drastically change the global economy and increase the inequality of incomes. First of all, it is the low-qualified and low-paid employees who suffer from robotic automation; their moving to postindustrial countries becomes unprofitable and unjustified, given the technological development and higher volumes of the contemporary digital economy. The fear of unemployment following the escalating automation is justified in the developing economies where it may be the question of replenishing the shortage of human capital and not of replacing man with technology. The upcoming transformation of labor market means not termination of employment for people but changing the specialization and emergence of demand for other kinds of work. Economic solutions in artificial intelligence are one of the sectors of global economy which is growing briskly. The next most important factor is the availability of human resources. The majority of the developed countries are creating the economic, intellectual, material and technical base for artificial intelligence to function; the work is being efficiently carried out e.g. in Japan, South Korea, China, in the countries of the European Union and North America. This is why in 
order not to stay behind on the fringes of the world social and economic development, people have to ratchet up actions in creation of digital economy and artificial intelligence.

In conditions of post-economy of artificial intelligence, an increasing quantity of skilled personnel have to be trained in the high-tech sphere. This is practicable by the joint efforts of the state and the largest technological companies and production. The authors believe the problem of shortage of qualified specialists can be resolved not only by education but also with the help of creating artificial intelligence. The latter can solve many problems in production and other spheres of reproduction - automation of routine work, the use of the potential of programmers in solving the complicated questions of technological process, creation of new innovation systems, output of products with a higher added value, and the use of artificial intelligence in the sphere of services - all this ultimately leads to a growth of productivity of labor. Thus, an entire economic and technological helix is created which leads to economic growth and sustainable development.

The emphasis on automation, robotic automation of labor and development of artificial intelligence may be one of the correct directions and the least problem-plagued one for the country, because neither robots nor artificial intelligence, nor various algorithms and applications need food or accommodation and other physiological and social transactions. They also create no load on the urban, production and economic infrastructure. What is essential for this is to develop the existing one and build a new system of education, scientific schools and directions on the basis of development of the competitive market environment.

\section{The unique situation of entrepreneurship in post-economy}

Artificial intelligence has a positive influence on the economy furthering the development of entrepreneurship. This results in a rapid development of productive powers of the society. Private investments into artificial intelligence grow quickly. Private research and developments, state investments into artificial intelligence have a great influence on the economic growth, and venture capital financing has a high effect as they contribute to the development of innovations and the capacity of the economy to use the existing knowledge for enhancing the productivity of labor.

There is the general opinion about the higher venture capital financing leading to the growth of macroeconomic indicators, such as the quantity of firms, employment and revenues. First of all, venture financing stimulates innovations. Secondly, venture investments cushion the limitations of capital owing to individual people participating in the entrepreneurial activity. Thirdly, investors can stimulate further development of entrepreneurship giving a boost to the market by entrepreneurs' higher expectations from project financing. Finally, venture investors can influence the economy by increasing the probability of other firms financed by large companies' encouraging the outsiders to commence their own entrepreneurial activity in the sphere of high technologies and artificial intelligence.

Creation and development of artificial intelligence in certain industries and spheres may be of mutual interest both for the state and for the business. Market subjects involved in cooperation with directive authorities conduct indepth research for better understanding and forecasting the development of artificial intelligence, considering, e.g. the circumstances of the region and industries, operation of automated systems at a more detailed level, the influence of timing, wage level, education, and national security. The joint efforts of the state and private sector of this kind can solve social problems, problems of ecology, security, other pernicious consequences of obsolete technologies, encourage and stimulate innovations, avoid centralization and expand independence in the decisionmaking process. 
The International Journal

ENTREPRENEURSHIP AND SUSTAINABILITY ISSUES

ISSN 2345-0282 (online) http://jssidoi.org/jesi/

2018 Volume 6 Number 2 (December)

http://doi.org/10.9770/jesi.2018.6.2(37)

The development of artificial intelligence will inevitably bring about the necessity of improvement of the legal framework, including one regulating the protection of the state interests, private life and public security. Meanwhile, there is a need to solve some general problems in maximizing the benefits and minimizing the risks: guiding principles for ensuring the security and investigation of failure processes have to be worked out, transparency systems for decision-making and management processes have to be designed, and public opinion has to be taken into account by means of efficient communication, and so on.

Therefore, the key feature of the current instant consists in artificial intelligence beginning to fulfill its potential for the business and for the state while throughout its history it has been referred to as a factor of significant contribution to the global economic growth.

Artificial intelligence opens up new opportunities for business. Companies are already successfully using the face recognition and voice identification functions for automating the existing products and services. New opportunities are opened up for the big business too. Smart systems are created that are capable of controlling air traffic or performing the integrated medical diagnostics. Such databases can be patented. However, in this market, it is extremely difficult to become the first or a large player. The data of artificial intelligence are frequently contained in open sources so they can easily become the common property.

Thus, the contemporary development of digital technologies leads to emergence of a new structure - virtual autonomous economy - the main element of which will be artificial intelligence that does not depend on people but works along certain virtual algorithms and applications.

There is the temptation of a total administrative control over these processes at the stage of establishment of this area that is still relatively small but the most promising and high-tech one. What is required is the optimum combination of the state and the private business which can make a qualitative takeoff in development of the digital economy and creation of artificial intelligence. The implementation of artificial intelligence will require taking quite a number of institutional, economic and legal measures aimed at regulating the spheres and branches of the national economy in the light of the smart technology transformation.

\section{Conclusions and discussions}

The main economic and social consequences of the rise of post-economy of artificial intelligence can be worded in general as follows.

First of all, the previous economy, including the postindustrial one based on production, placed into the foreground everything which would lead to economic growth. Meanwhile, in the economy of socially distributing type - where the priority is given to jobs and access to goods and services of mass demand is desirable - the economic growth is only possible if it creates jobs. For instance, in oil mining, hydraulic fracturing of formation can be justified because technologies considering the environmental aspect are taken into account little if at all due to the quantitative growth results being the priority. In conditions of post-economy of artificial intelligence, the mechanism of measuring the economic development level will be changed too. GDP is most suitable for productive, physical economy which does not duly consider the advance in virtual, smart environment. In posteconomy of artificial intelligence, the traditional quantitative indicators of economic growth will hardly be able to relevantly reflect the extent of intellectual and social advance in public relationships.

Secondly, non-regulated markets frequently bring about reservation of leading positions for several large companies. The firms losing the competitive struggle rarely get a compensation from the society. Previously, the employees of the firms used to be able to find other jobs, but this is known to be no longer an option in the 
The International Journal

ENTREPRENEURSHIP AND SUSTAINABILITY ISSUES

ISSN 2345-0282 (online) http://jssidoi.org/jesi/

2018 Volume 6 Number 2 (December)

http://doi.org/10.9770/jesi.2018.6.2(37)

economy of artificial intelligence. Economic efficiency of the market economy will be considered insufficient if it leads to generating an immense quantity of unemployed workers.

Thirdly, the spheres of application of artificial intelligence are fairly broad and they encompass both the habitual widespread technologies and the emerging new technologies and directions that are currently far from massive use. The entire diversity can be subdivided according to the criterion of the development "key points". Artificial intelligence is no monolithic subject area. Moreover, some technological directions of artificial intelligence act as new sub-industries of the economy and as standalone entities while at the same time serving most spheres in the economy.

Fourthly, two groups of use of artificial intelligence are subdivided into the physical and the virtual layers, with the virtual one prevailing. Developing the application of artificial intelligence along these lines will lead to using the technologies in traditional industries of the economy all round the perimeter of new value creation and transform them by creating a universal algorithm for almost the entire production and consumption functions range, from simple logistics to company management.

Fifthly, as for post-economy of artificial intelligence, it makes sense to single out two development directions: solving the problems associated with bringing the specialized artificial intelligence systems closer to human capabilities and their integration implemented by the human nature; and creating the artificial intelligence, arguably, a "mind", which would incorporate all the created artificial intelligence systems and would be able to solve many economic and social problems of the humanity.

\section{References}

Abrhám, J.; Bilan, Y.; Krauchenia, A.; Strielkowski, W. 2015. Planning horizon in labour supply of Belarusian small entrepreneurs. Economic research-Ekonomska istraživanja 28(1):773-787. https://doi.org/10.1080/1331677X.2015.1084238

Akutina A. Yu. 2014. "Kolmogorov complexity" and unpredictability of economic events. Achievements of university science No.11: 174176.

Atkinson, R. 2013. "Stop saying robots are destroying jobs". Technology review, September 3, 2013. Available from the Internet: https://www.technologyreview.com/s/519016/stop-saying-robots-are-destroying-jobs-they-arent

Balitskiy, S.: Bilan, Y.; Strielkowski, W. 2014. Energy security and economic growth in the European Union. Journal of Security \& Sustainability Issues 4(2):125-132. https://doi.org/10.9770/jssi.2014.4.2(2)

Bank of America. GDP budget-level forecast estimates for 2015-2025. Available from the Internet: http://databank.worldbank.org

Čábelková, I.; Strielkowski, W. 2013. Is the level of taxation a product of culture? A cultural economics approach. Society and Economy 35(4):513-529. https://doi.org/10.1556/SocEc.2013.0007

Čábelkova, I.; Strielkowski, W.; Mirvald, M. 2015. Business influence on the mass media: a case study of 21 countries. Transformations in Business \& Economics 14(1): 65-75.

Čajka, P.; Jaroszewicz, M.; Strielkowski, W. 2014. Migration Incentives and Flows between Belarus, Moldova, Ukraine and the European Union: a Forecasting Model. Economics and Sociology 7(4):11-25. https://doi.org/10.14254/2071-789X.2014/7-4/1

Cüneyt Dirican. 2015. The Impacts of Robotics, Artificial Intelligence on Business and Economics / World Conference on Technology, Innovation and Entrepreneurship // Procedia - Social and Behavioral Sciences. No. 195: 564-573. 
Ehrenberger, M.; Koudelkova, P.; Strielkowski, W. 2015. Factors influencing innovation in small and medium enterprises in the Czech Republic. Periodica Polytechnica Social and Management Sciences 23(2):73-83. https://doi.org/10.3311/PPso.7737

Fleming, W.; Pang, T. 2004. An Application of Stochastic Control Theory to Financial Economics. Available from the Internet: https://doi.org/10.1137/S0363012902419060/

Frey C.B.; Osborne, M.A. 2017. The future of employment: How susceptible are jobs to computerisation? Technological Forecasting and Social Change 114(issue C): 254-280.

Jensen, B.; Palokangas, T. 2007. Stochastic Economic Dynamics. Available from the Internet: https://books.google.ru/books?isbn=8763001853

Kalyugina, S.; Strielkowski, W.; Ushvitsky, L.; Astachova, E. 2015. Sustainable and secure development: facet of personal financial issues. Journal of Security \& Sustainability Issues 5(2): 297-304. https://doi.org/10.9770/jssi.2015.5.2(14)

Kendrick, D. 2005. Stochastic control for economic models: past, present and the paths ahead. Journal of Economic Dynamics and Control 29(1):3-30. https://doi.org/10.1016/j.jedc.2003.02.002

Koudelková P.; Strielkowski, W.; Hejlová, D. 2015. Corruption and system change in the Czech Republic: Firm-level evidence. DANUBE: Law and Economics Review 6(1):25-46. https://doi.org/10.1515/danb-2015-0002

Lisin, E.; Rogalev, A.; Strielkowski, W.; Komarov, I. 2015. Sustainable modernization of the Russian power utilities industry. Sustainability 7(9):11378-11400. http://dx.doi.org/10.3390/su70911378

Lisin, E.; Sobolev, A.; Strielkowski, W.; Garanin, I. 2016. Thermal efficiency of cogeneration units with multi-stage reheating for Russian municipal heating systems. Energies 9(4):269. https://doi.org/10.3390/en9040269

Malakhov D.I.; Pilnik N.P. 2015. Assessment methods for efficiency indicator in stochastic production frontier models. The Higher School of Economics Economic journal 17(4): 692-718.

Markoff, J. 2015. A Learning Advance in Artificial Intelligence Rivals Human Abilities. New York Times, December 10, 2015.

Nicholas Chen; Lau Christensen; Kevin Gallagher; Rosamond Mate; Greg Rafert. 2016. Global Economic Impacts Associated with Artificial Intelligence. Available from the http://www.analysisgroup.com/uploadedfiles/content/news_and_events/news/ag_executive_summary_economic_impact_of_ai.pdf

Nilsson, N. 1984. Artificial Intelligence, Employment and Income. Available from the Internet: http://ai.stanford.edu/ nilsson/OnlinePubsNils/General\%20Essays/AIMag05-02-002.pdf

Ricardo, D. 2003. On the principles of political economy and taxation. 3rd ed., Murray John, New York.

Steensma, H. K.; Lyles, M. A. 2000. Explaining IJV survival in a transitional economy through social exchange and knowledge-based perspectives. Strategic Management Journal 21(8):831-851. https://doi.org/10.1002/1097-0266(200008)21:8\%3C831::AID$\underline{\mathrm{SMJ} 123 \% 3 \mathrm{E} 3.0 . \mathrm{CO} ; 2-\mathrm{H}}$

Štreimikienè, D.; Strielkowski, W.; Bilan, Y.; Mikalauskas, I. 2016. Energy dependency and sustainable regional development in the Baltic states: A review. Geographica Pannonica 20(2):79-87. https://doi.org/10.5937/GeoPan1602079S

Strielkowski, W.; Čábelková, I. 2015. Religion, culture, and tax evasion: Evidence from the Czech Republic. Religions 6(2), 657-669. https://doi.org/10.3390/rel6020657

Strielkowski, W.; Lisin, E.; Tvaronavičienè, M. 2016b. Towards energy security: sustainable development of electrical energy storage, Journal of Security and Sustainability Issues 6(2): 235-244. http://dx.doi.org/10.9770/jssi.2016.6.2(4) 
The International Journal

ENTREPRENEURSHIP AND SUSTAINABILITY ISSUES

ISSN 2345-0282 (online) http://jssidoi.org/jesi/

2018 Volume 6 Number 2 (December)

http://doi.org/10.9770/jesi.2018.6.2(37)

Strielkowski, W.; Tumanyan, Y.; Kalyugina, S. 2016a. Labour Market Inclusion of International Protection Applicants and Beneficiaries. Economics and Sociology 9(2):293-302. https://doi.org/10.14254/2071-789X.2016/9-2/20

Strielkowski, W.; Weyskrabova, B. 2014. Ukrainian Labour Migration and Remittances in the Czech Republic. Tijdschrift voor economische en sociale geografie 105(1):30-45. https://doi.org/10.1111/tesg.12052

The Economist. 2001. Predicting the unpredictable. Some physicists think they can see into the future of markets. 2001. May $31^{\text {st }}, 2001$. Available from the Internet: / https://www.economist.com/node/638530

Tvaronavičienè, M. 2018. Preconditions of sustainable entrepreneurship: estimating of Brexit scenarios' impact on macroeconomic environment. Polish Journal of Management Studies 17(2): 222-234 https://doi.org/10.17512/pjms.2018.17.2.19

Tvaronavičienè, M. 2018. Toward efficient policy making: forecasts of vulnerability to external global threats. Journal of Security and Sustainability Issues 7(3): 591-600. https://doi.org/10.9770/jssi.2018.7.3(18)

Tvaronavičienè, M., Tarkhanova, E., \& Durglishvili, N. 2018. Sustainable economic growth and innovative development of educational systems. Journal of International Studies 11(1): 236-244. https://doi.org/10.14254/2071-8330.2018/11-1/19

Ushankov V.A. 2014. Post-economy - the contemporary stage of post-industrial development of the economy. Problems of modern economics 4(52): 54-56.

Vorontsovskiy, A.V.; Viyunenko, L.F. 2016. Forecasting development of the economy based on the stochastic model of economic growth considering turning point. Bulletin of Saint-Petersburg University. $\quad$ Series 5 : Economics (4): 4-32. https://doi.org/:10.21638/11701/spbu05.2016.401

World Economic Forum. 2017. The Future of Jobs. Labor market development forecast. Available from the Internet: https://www.conference-board.org

Zemlickiene, V.; Mačiulis, A.; Tvaronavičienė, M. 2017. Factors impacting the commercial potential of technologies: expert approach. Technological and Economic Development of Economy, 23(2): 410-427 http://dx.doi.org/10.3846/20294913.2016.1271061

\section{Oktay MAMEDOV \\ ORCID ID}

\section{Yuri TUMANYAN}

ORCID ID

\section{Oksana ISHCHENKO-PADUKOVA \\ ORCID ID}

\section{Irina MOVCHAN}

ORCID ID

Register for an ORCID ID:

https://orcid.org/register

Copyright (C) 2018 by author(s) and VsI Entrepreneurship and Sustainability Center

This work is licensed under the Creative Commons Attribution International License (CC BY).

http://creativecommons.org/licenses/by/4.0/

(c) (†) Open Access 